Experimental Study (1936). A progress report was thus long overdue, and the author has risen to the occasion with distinction.

DAVID BARKER

\section{BAEDECKER OF THE BRAIN}

\section{The Human Brain in Figures and Tables}

A Quantitative Handbook. By S. M. Blinkov and I. I. Glezer. Translated from the Russian by Basil Haigh. Pp. xxxii +482 . (Basic Books and Plenum Press: New York, 1968.) $\$ 25$.

THIs is described as a quantitative handbook and marks the beginning of the quantitative epoch in neurosciences as distinct from the usual descriptive works on the brain.

A large part of the book is text but more than 160 pages are devoted to tables at the end and there are over 1,000 references, largely from the English literature. It is, however, more than a dull collection of figures, for the information is arranged with originality throughout the text.

This is a fascinating, almost encyclopaedic, collection chiefly about histological measurement with tantalizingly brief references to electrophysiological measurements such as conduction velocities in particular fibre groups.

One of the most important chapters is on techniques of quantitative measurement: a very interesting and critical analysis of quantitative techniques used in neuroanatomy describing common errors and how to avoid them. It is full of formulation for calculating brain volume from moasurements of sections, but it still in. cludes an unusually practical discussion of errors introduced during microtome sections. There is information on the external dimensions of the brain and cord, the number and total volume of neurones, three fascinating chapters on the cerebral cortex detailing its volume, surface area and the number and dimensions of its cells. The chapter on cranial nerves is exceptionally detailed with quantitative data on nuclei and information correlating the statistical information obtained on cells and their fibres. The authors have gathered a vast amount of information and they have chosen to comment wisely and interestingly on much of the information presented.

It is not a book to read from beginning to end, but each page conveys information obtained only laboriously from works of scholarship in a variety of languages. It has becn described as a Baedecker of the nervous system: an apt description because it excels in fact rather than opinion. The information is weighty, exhaustive and extraordinarily impressive.

The title is something of a misnomer because a great deal of the information relates to animal work, not human, although generally the text is arranged so that human and animal results are clearly discernible. In this way it is possible to see the vast amount of information available on animals and the paucity of human measurements. It also reveals our inadequate knowledge about structures which many would regard as familiar. An invaluable reference book for the neurohistologist, this neural encyclopaedia will have a very wide appeal.

EDWARD HITCHCOCK

\section{ANIMAL PARADE}

The Procession of Life

By Alfred S. Romer. Pp. viii $+323+48$ plates. (The Weidenfeld and Nicolson Natural History.) (Weidenfeld and Nicolson: London, 1968.) $63 s$.

Is The Procession of Life Romer extends his evolutionary writings to eover the main groups of animals from protozoans to man. The search for the selective forces respons. ible for the evolution of these groups provides the unifying theme. Understandably, Romer devotes more space to the vertebrates than to the invertebrates. But to read a vertebrate palaeontologist's views on the evolution of invertebrates is refreshing. The case he makes, for example, for the relationships of the invertebrate filterfeeders and the derivation of the echinoderms from them may not be either original or profound but the simple approach makes its point and helps the general reader to think through this crowd of little-known animals. $\mathrm{He}$ has picked on the chief morphological resemblances between groups to emphasize them at the expense of other less obvious attributes. This treatment applied to arthropod segmentation, for example, makes sense to the general reader and the student beginning zoology.

The Procession of Life must be one of the few books covering the whole animal kingdom that is likely to be read by beginners. But in his effort to be acceptable to these readers the author uses a casual style which, on the positive side, may be said to give confidence but, on the negative, becomes irritating and, in some cases, damaging to the thesis. Romer is, as he himself points out in the first chapter, a strict Darwinian selectionist and therefore when he writes "many mammals have modified their limbs into efficient hoofed running organs" he does not mean that some internal striving of the animals has brought this about. The author is writing in the casual way that zoologists talk which, though producing vivid images, is misleading.

It is pleasant to find new diagrams of a high standard throughout. A particularly good one of the phylogeny of fishes makes it obvious that there are no diagrams of invertebrate phylogenies and only one other to cover the rest of the vertebrates. It would have been good to see the author take the risk of committing himself pictorially to some invertebrate relationships. But his attitude to writing on invertebrates is apologetic.

Some exciting new reconstructions of fossil vertebrates have been prepared for this book and the choice of photographs of living animals, particularly of mammals, is ingenious. The selection and the juxtaposition with the fossil reconstructions has the unusual effect of making modern animals look just as fantastic as some think their predecessors.

The book is well produced but marred by the curious pedantry of the London editor. The spelling Paleocene is changed to Palaeocene throughout the book except in the index. Hippopotami and hyraces remain unchanged throughout the book and one hyrax has a separate entry in the index.

Wilma George

\section{FISH PRODUCTION}

\section{Methods for Assessment of Fish Production in Fresh} Waters

Edited by W. E. Ricker. (International Biological Programme Handbook, No. 3.) Pp. xiii + 313. (Blackwell Scientific Publications: Oxford and Edinburgh, 1968. Published for the International Biological Programme.) 37s. $6 d$.

THE publication of this handbook marks an important step forward in the field of fisheries research. It has been produced primarily for the guidance of young graduates taking part in the International Biological Programmo all over the world, but it will find its way to the bookshelves of tho more experienced worker as well as the uninitiated.

In thirteen chapters written by nineteen international experts the basic techniques of fisheries work are well described and illustrated. Although the title of the book suggests that the assessment of the production of fish in fresh waters is the main purpose of the work, anyone who is at all concerned in the major fields of fisheries research will find it has something to offer him.

The work includes useful chapters on sampling methods; 